University of Nebraska - Lincoln

DigitalCommons@University of Nebraska - Lincoln

Nebraska Cooperative Fish \& Wildlife Research Nebraska Cooperative Fish \& Wildlife Research Unit -- Staff Publications

2001

\title{
Modeling viable mammal populations in gap analyses
}

Craig R. Allen

University of Florida, callen3@unl.edu

L. G. Pearlstine

University of Florida, pearlstn@ufl.edu

Follow this and additional works at: https://digitalcommons.unl.edu/ncfwrustaff

Part of the Other Environmental Sciences Commons

Allen, Craig R. and Pearlstine, L. G., "Modeling viable mammal populations in gap analyses" (2001).

Nebraska Cooperative Fish \& Wildlife Research Unit -- Staff Publications. 16.

https://digitalcommons.unl.edu/ncfwrustaff/16

This Article is brought to you for free and open access by the Nebraska Cooperative Fish \& Wildlife Research Unit at DigitalCommons@University of Nebraska - Lincoln. It has been accepted for inclusion in Nebraska Cooperative Fish \& Wildlife Research Unit -- Staff Publications by an authorized administrator of DigitalCommons@University of Nebraska - Lincoln. 


\title{
Modeling viable mammal populations in gap analyses
}

\author{
Craig R. Allen *, L.G. Pearlstine, W.M. Kitchens \\ US Geological Survey, Biological Resources Division, Florida Cooperative Fish and Wildlife Research Unit, \\ Department of Wildlife Ecology and Conservation, University of Florida, Gainesville, FL 32611, USA
}

Received 6 August 1999; received in revised form 6 April 2000; accepted 2 May 2000

\begin{abstract}
Gap analysis is an approach to conserving biological diversity that maps species richness and identifies sites that ought to be protected but are not in conservation networks. Gap analyses based on species richness may have high error rates when species models are based solely on species-habitat associations, because patches too small to support populations are still considered to be potential habitat. We incorporated information on the home range and dispersal distances of the mammals of Florida to estimate minimum critical areas (MCA) to support minimum viable populations for each mammal species. Incorporating MCA decreases the area occupied by the highest levels of species richness, and alters the mapped spatial distribution of potential species richness. For example, in St. Lucie and Okeechobee counties, Florida, the total area occupied by 15 or more species was 30,448 ha under simple mammal-habitat association models, but only 7820 ha under model conditions incorporating MCA. This reflects the fragmented condition of many landscapes, where most patches are too small to support viable populations of larger species. Incorporating minimum area requirements into maps of potential species richness produces more conservative and defensible maps. (C) 2001 Elsevier Science Ltd. All rights reserved.
\end{abstract}

Keywords: Biodiversity; Conservation; Gap analysis; Spatially explicit models; Species richness

\section{Introduction}

Many species, communities, and ecosystems are presently imperiled, and there is an urgent need for establishing efficient ways to inventory and monitor areas for inclusion in conservation networks. Using one or a few species for the identification and development of reserve systems or conservation plans is a narrow approach which may result in the protection of one organism at the expense of another (Hurro et al., 1987; Landres et al., 1988).

To counter the problems of using single species in conservation decision-making, the use of indicator species (Noss, 1990), guilds (Severinghaus, 1981; Landres, 1983; Verner, 1984), or umbrella species (Shafer, 1990) has been advocated as efficient methods for identifying areas in need of protection. Recently, the US Fish and Wildlife Service initiated a program called Gap Analysis

* Corresponding author. Present address: US Geological Survey, Biological Resources Division, South Carolina Cooperative Fish and Wildlife Research Unit, Clemson University, Clemson, SC, 29634, USA. Tel.: + 1-864-656-4461; fax: + 1-864-656-1034.

E-mail address: allencr@clemson.edu (C.R. Allen). to identify areas of high biological diversity that are not protected by existing reserves (Scott et al., 1993; The National Gap Analysis program is now managed by the Biological Resources Division of the USGS). This approach uses vertebrate species richness as an index for overall biological diversity (Scott et al., 1987). Species richness is determined by creating spatial models of potential species habitat and determining nodes of high species richness by producing composites of the individual models. Similar techniques guide conservation efforts throughout the world (Miller, 1994). Because of the availability of data, relative ease of sampling, and public appeal, most of these studies have focused on vertebrates.

The Gap Analysis approach was developed in the western United States where landforms are extensive and land ownership patterns outside of developed areas are also extensive. In the eastern United States, however, land ownership patterns occur in smaller patches and landcover types occur in a much more complex mosaic. In general, development pressures are greater in the eastern United States, and opportunities for protecting large areas under public ownership are limited or no longer 
exist. Remaining undeveloped lands for habitat protection and/or purchase are likely to be an order of magnitude smaller in the east as opposed to much of the western United States. In Florida for example, useful conservation scales determined from vertebrate species richness are likely to be in the range of hundreds to thousands of hectares (e.g. Cox et al., 1994), rather than tens of thousands of hectares. The smaller spatial extent of conservation decision-making in the eastern United States led the state of Florida to conduct its spatial analysis of species richness at a high spatial resolution. Landcover was classified at a resolution of $30 \mathrm{~m}$.

Mapping at a higher resolution, especially where this leads to the creation of more habitat classes, creates new problems in species mapping, especially by potentially inflating errors of commission, the chance of erroneously including the presence of a species in a habitat where it is absent. Species models are generated by creating association matrices among species and landcover types (Scott et al., 1993). On high-resolution maps, commission errors are likely to be high when creating species models based simply on species-habitat associations. A habitat patch as small as $30 \mathrm{~m}$ may be identified as a discrete unit. However, a discrete $30-\mathrm{m}$ patch in isolation will not support a species with anything but a miniscule home range, and considerably larger patches will not support a viable population of many vertebrates.

Protecting biodiversity requires the protection of sustaining populations of all species into the foreseeable future. Protecting species requires sufficient habitat to support a minimum viable population over time. We incorporated information on the home range and dispersal distances of the mammals of Florida to estimate minimum critical areas (MCA) to support minimum viable populations (MVP) for each mammal species. Incorporating home range and dispersal distances should increase the accuracy of species models by reducing the commission error rate. Here, we describe our methods for modeling the mammal fauna of Florida by incorporating minimum viable population criteria, and compare those results with maps of species richness produced without consideration of viable population criteria. We were specifically interested in changes in the modeled spatial distribution and extent of species richness when using MCA criteria, rather than attempting to determine precise estimates of MVP or MCA for individual species.

\section{Methods}

\subsection{Landcover}

St. Lucie and Okeechobee counties, Florida, represent a complex mosaic of habitat types and land uses that are typical of much of the urbanizing eastern seaboard of the United States. Landcover was mapped from the classification of 1993 and 1994 Landsat Thematic Mapper satellite imagery. Bands 2,3,4, and 5 of the imagery and a Tassel Cap transformation (Crist and Cicone, 1994) were used in an iterative unsupervised clustering algorithm. Labeling of the spectral clusters with vegetation associations followed The Nature Conservancy/ UNESCO, Southeastern Region classification scheme (The Nature Conservancy, 1997). This hierarchical, ecologically based classification scheme delineates plant associations in the southeast United States. The UNESCO classification scheme is the basis for the National Vegetation Classification Standard adopted by the Federal Geographic Data Committee. Labeling was assisted with auxiliary information from South Florida Water Management District land use/land cover maps, National Wetlands Inventory maps, SSURGO soils maps and photo interpreted points from low altitude aerial videography.

\subsection{Species-habitat models}

Independent models were developed for all native terrestrial (i.e. excluding bats) mammals presently extant in the study area. Mammal distributions were determined by surveying state and national museums holding collections of Florida vertebrates, and from published sources (e.g. Blair, 1935a,b; Hamilton, 1941; Moore, 1946; Pournelle, 1950; Sherman, 1952; Pearson, 1954; Starner, 1956; Ivey, 1959; Chapman and Feldhamer, 1982; Layne, 1984). The distribution of endangered and declining species, which are more likely to have experienced recent changes in distribution, was determined primarily from Humphrey (1992a). Additional data on mammal distribution was provided by the Wildlife Observation database of the Florida Game and Fresh Water Fish Commission and by the American Society of Mammalogists series 'Mammalian Species'. Resulting state-wide, county-level distribution maps were reviewed by recognized experts in the field of mammalogy.

Habitat affinities for mammals were determined primarily from literature review. The Florida species habitat/ecology bibliography includes $>1300$ sources that have been used to create descriptors of habitat use by species. That bibliography may be accessed through the internet at: http://coop.wec.ufl.edu/gap. This information was used to build a matrix of species versus landcover types, where every mammal species was determined to be present or absent in each landcover type.

\section{3. $M V P$ area requirements}

The home range and dispersal distances of terrestrial Florida mammals also were determined from extensive literature reviews. We preferentially used estimates from 
studies in Florida, but where home range or dispersal estimates specific to Florida were not available we used estimates from nearby locations (Table 1). Home range estimates were used to calculate the area required to support a MVP. For our purposes, we crudely defined MVP as being equal to 50 individuals, the estimated minimum number of individuals necessary to persist despite demographic stochasticity (Shaffer, 1981). Note that we do not assume that 50 is the 'real' MVP size for mammals (see Section 4), nor that a MVP can be truly defined, rather we chose this conservative value to investigate and illustrate changes, if any, in the spatial distribution and extent of species richness mapped at a landscape-scale (i.e. across a broad heterogeneous land area). The MCA required to support a MVP for each species was calculated by multiplying home range estimates by 50 , and dividing by two. Dividing by two accounted for intersexual overlap among home ranges. Inter- and intrasexual home range overlap varies considerably among species; we chose complete overlap between sexes to produce conservative comparative models.

\subsection{Incorporating dispersal}

Patches of suitable habitat too small to support a MVP may still be occupied if these areas are within the dispersal distance of a species. Patches supporting a MVP were buffered by the dispersal distance of each species as determined from the literature (Table 1) and those smaller patches within the dispersal distance of a species also were considered utilized habitat. Estimates of dispersal distances available in the literature often reflected unusual events, or maximal dispersal distances. To partially compensate for that, and provide conservative estimates, we divided literature-derived dispersal estimates by two. As with MVP, our goal was not to precisely model individual species, but to measure the effect of the addition of these parameters on the spatial distribution of species richness.

\subsection{Analysis}

We generated three mammal species richness maps for St. Lucie and Okeechobee counties, Florida. The simplest

Table 1

Home range and dispersal distance estimates (hectares and meters) for the mammals of St. Lucie and Okeechobee counties, Florida

\begin{tabular}{|c|c|c|c|c|c|}
\hline Species & $\begin{array}{l}\text { Home } \\
\text { range }\end{array}$ & $\begin{array}{l}\text { Minimum critical } \\
\text { area estimate }\end{array}$ & Source & Dispersal & Source \\
\hline Blarina carolinensis & 0.96 & 24 & Faust et al. (1971) & 47 & Burt (1940) \\
\hline Cryptotis parva & 0.20 & 5.00 & Howell (1954) & NA & \\
\hline Didelphis virginiana & 128.5 & 3213 & Ryser (1995) & 125 & Chapman and Feldhamer (1982) \\
\hline Felis concolor & 35600 & 890000 & Maehr et al. (1991) & 58700 & Maehr et al. (1992) \\
\hline Felis rufus & 2000 & 50000 & Wassmer et al. (1988) & 11000 & Bradley and Fagre (1988) \\
\hline Geomys pinetus & 0.31 & 7.7 & Hickman and Brown (1973) & NA & \\
\hline Glaucomys volans & 2.2 & 55 & Bendel and Gates (1987) & 339 & Burt (1940) \\
\hline Lutra canadensis & 14500 & 362500 & Reid et al. (1994) & 10000 & Chapman and Feldhamer (1982) \\
\hline Mephitis mephitis & 22.2 & 555 & Shirer and Fitch (1970) & 600 & Chapman and Feldhamer (1982) \\
\hline Microtus pinetorum & 0.1 & 2.5 & Nowak (1991) & 48 & Benton (1955) \\
\hline Mustela frenata & 14 & 350 & Chapman and Feldhamer (1982) & 214 & Chapman and Feldhamer (1982) \\
\hline Neofiber alleni & 0.005 & 0.125 & Birkenholz (1963) & 426 & Birkenholz (1963) \\
\hline Neotoma floridana & 0.7 & 17.5 & HaySmith (1995) & NA & \\
\hline Ochrotomys nuttali & 0.48 & 12 & Faust et al. (1971) & 73 & Blus (1966) \\
\hline Odocoileus virginianus & 32.5 & 813 & Kilgo (1992) & 2600 & Holzenbein and Marchinton (1992) \\
\hline Oryzomys palustris & 0.25 & 6 & Birkenholz (1963) & 175 & Forys and Dueser (1993) \\
\hline Peromyscus gossypinus & 0.18 & 4.5 & Layne (1974) & 130 & Pournelle (1950) \\
\hline Peromyscus polionotus & 0.14 & 3.5 & Davenport (1964) & 25 & Extine and Stout (1987) \\
\hline Podomys floridanus & 0.33 & 8.3 & Jones (1995) & 11 & Jones (1990) \\
\hline Procyon lotor & 260 & 6500 & Walker (1993) & 15100 & Clark et al. (1989) \\
\hline Reithrodontomys humilus & 0.51 & 12.8 & Layne (1974) & NA & \\
\hline Scalopus aquaticus & 0.69 & 17 & Harvey (1976) & 459 & Chapman and Feldhamer (1982) \\
\hline Sciurus carolinensis & 0.47 & 11.6 & Nowak (1991) & 4258 & Jackson (1961) \\
\hline Sciurus niger & 25 & 625 & Humphrey (1992b) & 4100 & Wooding (1994) \\
\hline Sigmodon hispidus & 0.22 & 5.5 & Odum (1955) & NA & \\
\hline Sorex longirostris & 0.04 & 0.93 & Nowak (1991) & NA & \\
\hline Spilogale putorius & 64 & 1600 & Nowak (1991) & 3840 & Kinlaw et al. (1995) \\
\hline Sylvilagus floridanus & 2.5 & 63 & Anderson and Pelton (1976) & 2352 & $\begin{array}{l}\text { Jackson (1961)/Litvaitis } \\
\text { and Villafuerte (1996) }\end{array}$ \\
\hline Sylvilagus palustris & 3.9 & 98 & Forys (1995) & NA & \\
\hline Urocyon cinereoargentus & 550 & 13750 & Sunquist (1989) & 3151 & Storm (1965) \\
\hline Ursus americana & 8000 & 200000 & Wooding and Hardisky (1993) & 26500 & Wooding et al. (1992) \\
\hline
\end{tabular}




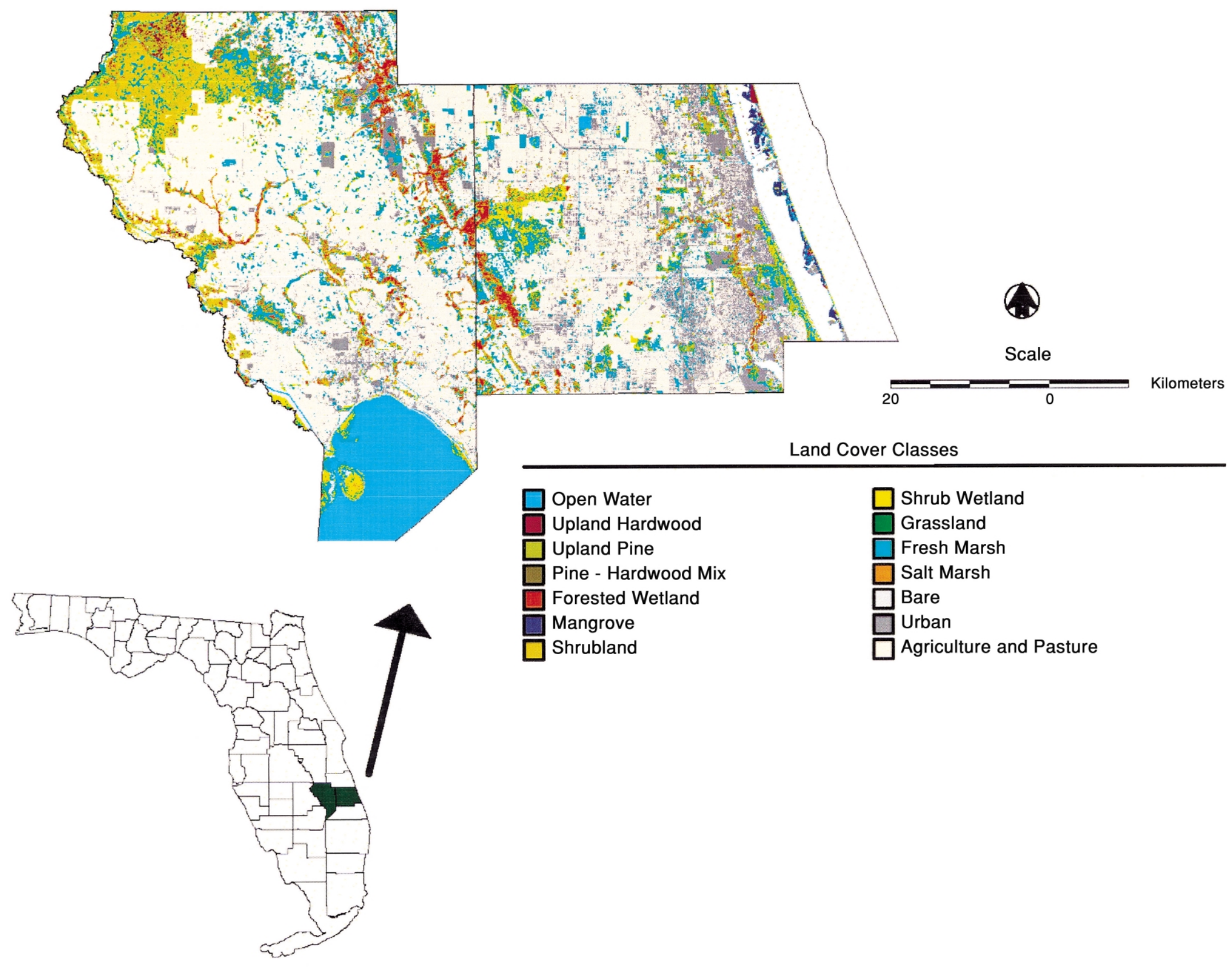

Fig. 1. Natural area landcover of St. Lucie and Okeechobee counties, southwest Florida. 
model was based on species habitat associations only. We compared the output of that model with the output of the model incorporating MCA and the model incorporating both MCA and dispersal. We determined patterns of species richness derived from all models and conducted comparisons of the spatial distribution and extent of mammal species richness among the three different models.

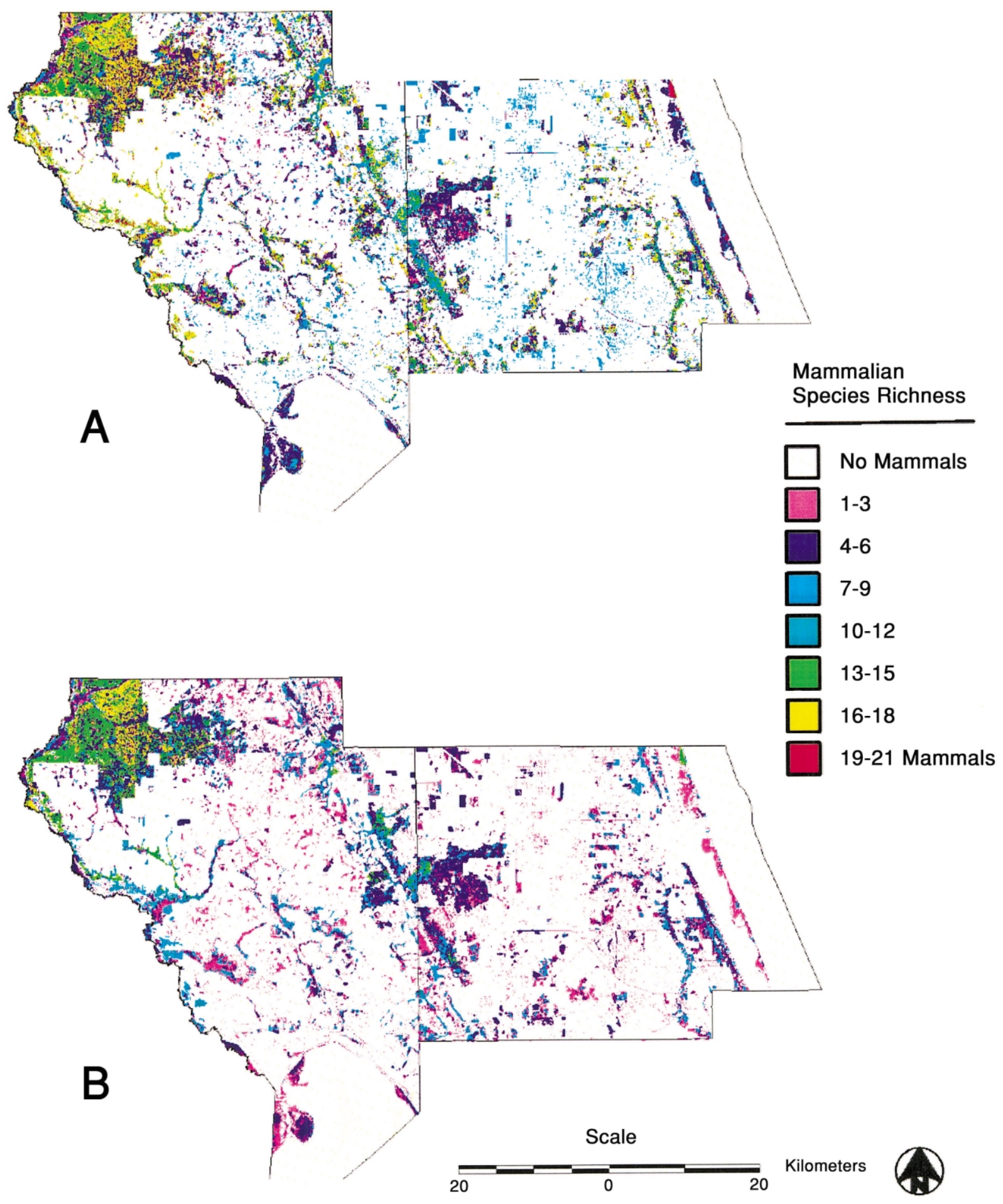

Fig. 2. (A) The spatial distribution of mammal species richness in St. Lucie and Okeechobee counties, southwest Florida, based on simple habitat associations. (B) The spatial distribution of mammal species richness in St. Lucie and Okeechobee counties, southwest Florida, incorporating 


\section{Results}

\subsection{Landcover}

We classified 72 different landcover types in St. Lucie and Okechobee counties (Fig. 1), including urban and agricultural classes. Of the total 375,745 ha of St. Lucie and Okechobee counties, 252,900 ha were classified as urban or row crops, and were excluded from this analysis. Of the remaining 122,798 ha, 23,700 ha were open water, which also were excluded from our analysis. Urban and aquatic classifications were not modeled as barriers for dispersal. Thus, a total of 99,102 ha were considered natural areas and were the focus of our efforts.

\subsection{Species-habitat models}

Thirty-seven native terrestrial mammals may inhabit St. Lucie and Okechobee counties. Mammal species richness ranged from 1 to 21 for any given landcover class. In general, richness was highest in productive, forested upland classes and lowest in marshes (Fig. 2A).

\subsection{MVP area requirements}

Excluding areas of potential habitat that were too small to support a MVP led to significant changes in the spatial distribution of species richness (Fig. 2B) and the extent of different levels of species richness (Fig. 3). After incorporating MCA criteria, maximum richness was 20 species, and at levels of richness of 15 and greater, the extent of a given level of species richness was dramatically decreased (Figs. 2B and 3). The total extent of richness levels $\geqslant 15$ species was 30,448 ha under simple mammal-habitat association models but only 7820 ha under model conditions incorporating minimum viable populations. This reflects the fragmented condition of the landscape, where most patches are too small to support viable populations of larger species. The differences in modeled species distributions under the assumptions of the species habitat model versus the MCA model may be best illustrated by examining the distribution of a single species. Fig. 4 maps the spatial distribution of the long-tailed weasel (Mustela frenata) based on simple species-habitat association. Fig. 5 maps its spatial distribution after incorporating MCA criteria.

\subsection{Incorporating dispersal}

Incorporating dispersal did not substantially change the area occupied by different levels of species richness, nor the overall spatial distribution of that richness, as compared to the simpler MCA model (Fig. 3).

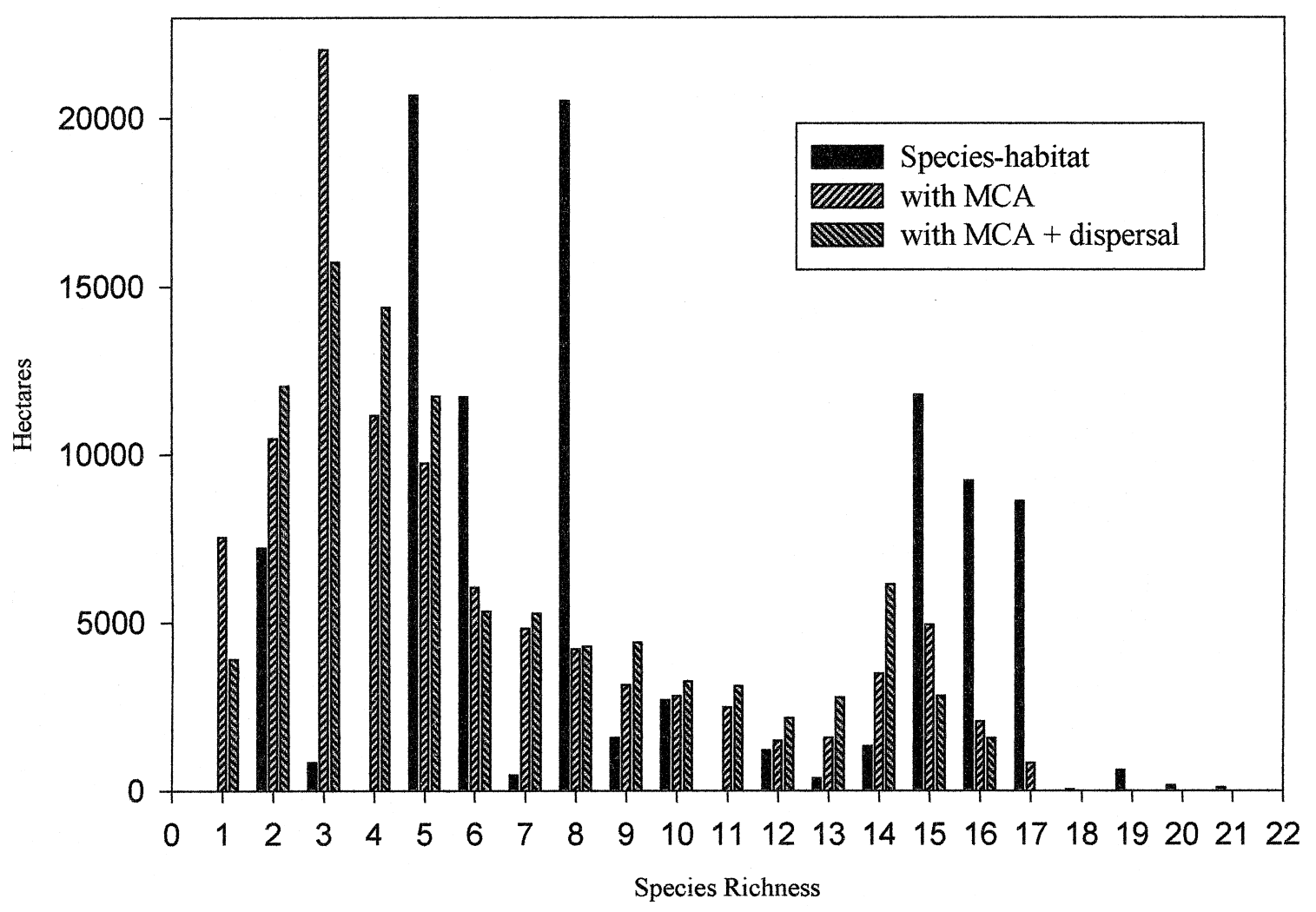

Fig. 3. Comparison of the area occupied by different levels of species richness generated by three different models. The estimated area (hectares) occupied by any given level of richness changes when one incorporates minimum critical areas (MCAs) and dispersal into the models of potential species habitat. Under the MCA model, areas of richness as high as 20 still exist, yet comprise less than 10 total hectares. 


\section{Discussion}

Incorporating MCA decreased the spatial extent of the highest levels of species richness, and altered the mapped distribution of potential species richness upon the landscape. We suggest that the incorporation of MCA estimates and dispersal distances more realistically captures patterns of mammal diversity on landscapes. Models based on habitat requirements may be too simple, particularly where habitats are fragmented. Population parameters must be incorporated into spatial animal models (Conroy and Noon, 1996). We have argued that in the eastern United States, only small areas are likely to be added to the conservation system. However, incorporating MCA estimates highlights that, for mammals at least, small patches are unlikely to support much in the way of vertebrate diversity.

Note that in determining MVP size we used an estimated minimum population size of 50, the estimated size necessary to avoid extinction due to demographic stochasticity. To avoid the loss of genetic heterozygosity resulting from inbreeding and genetic drift, the MVP size would be in the order of 500 individuals (Franklin, 1980; Soulé, 1980). Given the larger MVP criteria, Minimum Critical Areas for most large vertebrates would be difficult to accommodate in Florida outside of areas presently under federal ownership.
The species-model refinements we described are possible for most mammals because home range information is available for most mammal species. The inclusion of these data is most critical when mapping large species (i.e. vertebrates) at a high resolution. Our estimates for MVP and MCA were crude. However, we believe that the resulting maps of species richness are more biologically realistic than those generated by simple habitat associations. Furthermore, developing MCA estimates for individual species based on known inter- and intra-sexual overlap would be straightforward for well-studied species, but developing precise MCA estimates was not the purpose of our efforts. Refinements in terms of better estimates of MCA, based on known home range overlap and better estimates of dispersal would be relatively simple to incorporate. Refinement of dispersal models is possible but gathering accurate data remains challenging, and available dispersal data is often of poor quality or quantity. However, given the importance of dispersal in metapopulation dynamics (Gilpin and Hanski, 1991), further investigation of the impact of dispersal on Gap models is warranted. Recognizing dissimilar dispersal barriers - or bridges for each species in the models is probably beyond the present scope of Gap Analysis. Additionally, adding dispersal to our models had little impact on overall results.

Spatial vertebrate models can be improved with the application of landscape ecology principles. Spatially

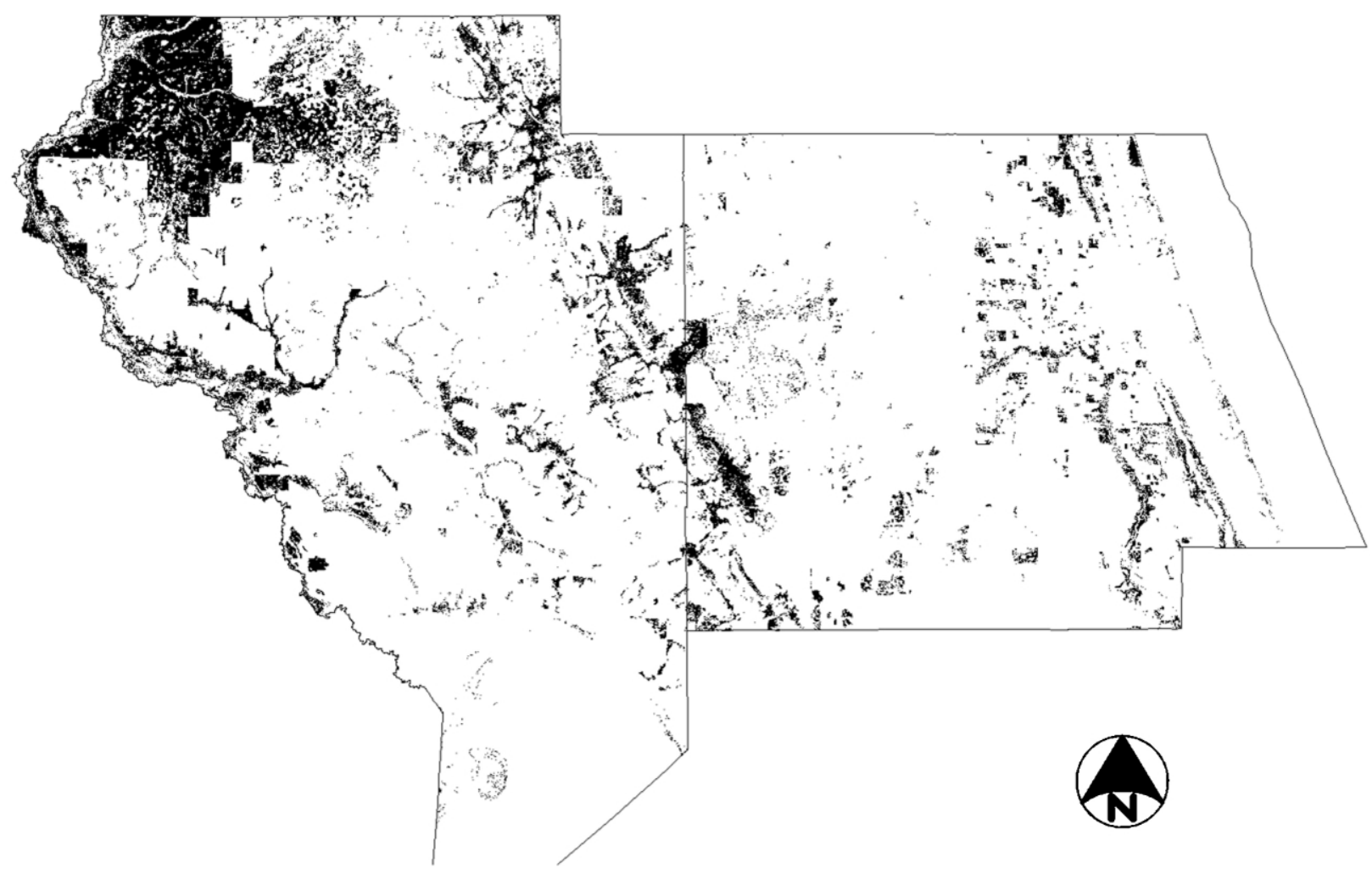

Fig. 4. The spatial distribution of Mustela frenata in St. Lucie and Okeechobee counties, southwest Florida, based on habitat association. 


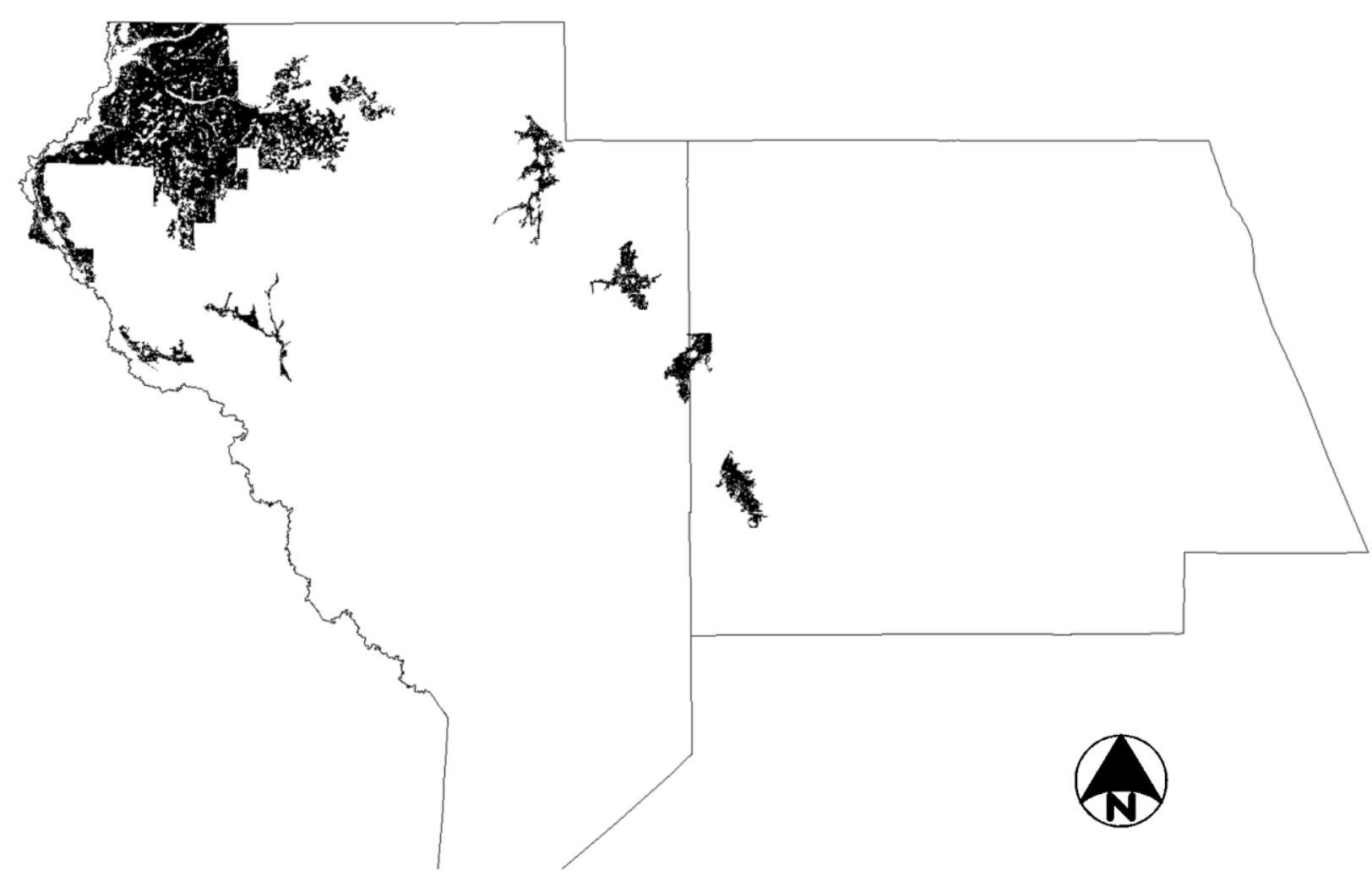

Fig. 5. The spatial distribution of Mustela frenata in St. Lucie and Okeechobee counties, southwest Florida, after incorporating minimum critical area criteria.

explicit, population-level modeling that incorporates minimum viable populations, metapopulation (Levins, 1969; Gilpin and Hanski, 1991) and source and sink dynamics (Pulliam, 1988) and landscape connectivity will better reflect the interplay between species distribution and landscape elements. However, for some groups, basic natural history information is still lacking, and unlikely to be forthcoming in the near future.

\section{Conservation implications}

Examining the spatial patterns of species richness upon landscapes, as exemplified by Gap Analysis, is a powerful tool for conservation planning (Prendergast et al., 1999). It is necessary to ensure that those maps are as accurate as possible. Maps with high commission error rates will have little credibility and could mislead policy makers who engage in substantial political risk by advocating one particular conservation scheme over another. Incorporating minimum area requirements into maps of potential species richness may produce more conservative, biologically realistic, and defensible maps. Gap Analysis will be an effective tool for conservation planning as long as it continues to respond to criticisms and incorporate methodological advances (Burke, 2000).

\section{Acknowledgements}

We wish to thank the many individuals involved in the Florida Biological Diversity Project for making analyses such as this possible. Those persons include S. Smith, J. Stenberg, L. Brandt, L. Ojanen, A. Abd-elrahman, N. Ansay, J. Aufmuth, V. Boycheva, C. Fenex, M. Frankenberger, P. Gonzalez, M. Cook, D. Reed and R. Winstead. We thank J. Eisenberg and B. Milsap for reviewing our mammal distribution maps. The South Carolina Cooperative Fish and Wildlife Research Unit is jointly supported by a cooperative agreement among the USGS/ BRD, the South Carolina Department of Natural Resources, Clemson University, and the Wildlife Management Institute. This study was funded, in part, by the Florida Agricultural Experiment Station, Journal Series no. R07876.

\section{References}

Anderson, B.F., Pelton, M.R., 1976. Movements, home range, and cover use: factors affecting the susceptibility of cottontails to hunting. Proceedings of Southeastern Association of Game and Fish Commissions 30, 525-535.

Bendel, P.R., Gates, J.E., 1987. Home range and microhabitat partitioning of the Southern flying squirrel Glaucomys volans. Journal of Mammology 68, 243-255. 
Benton, A.H., 1955. Observations on the life history of the northern pine mouse. Journal of Mammalogy 36, 52-62.

Birkenholz, D.E., 1963. A study of the life history and ecology of the round-tailed muskrat (Neofiber alleni) in north central Florida. Ecological Monographs 33, 255-280.

Blair, F.W., 1935a. The mammals of a Florida hammock. Journal of Mammology 16, 271-277.

Blair, F.W., 1935b. Some mammals of southern Florida. American Midland Naturalist 16, 801-804.

Blus, L.J., 1966. Some aspects of golden mouse ecology in southern Illinois. Transactions of the Illinois State Academy of Science 59, 334-341.

Bradley, L.C., Fagre, D.B., 1988. Movements and habitat use by coyotes and bobcats on a ranch in southern Texas. Proceedings of the Southeastern Association of Fish and Wildlife Agencies 42, 411-430.

Burke, V. J. 2000. Landscape ecology and species conservation. Landscape Ecology 15, 1-3.

Burt, W.H., 1940. Territorial behavior and populations of some small mammals in southern Michigan. Miscellaneous Publications in Zoology, University of Michigan 45, 1-58.

Chapman, J.A., Feldhamer, G.A., 1982. Wild Mammals of North America. The Johns Hopkins University Press, Baltimore, MD.

Clark, W.R., Hasbrouck, J.J., Kienzler, J.M., Glueck, R.F., 1989. Vital statistics and harvest of an Iowa raccoon population. Journal of Wildlife Management 53, 982-990.

Crist, E.P., Cicone, R.C., 1994. Application of the tasseled cap concept to simulated thematic mapper data. Photogramm. Engr. Remote Sens. 50, 343-352.

Conroy, M.J., Noon, B.R., 1996. Mapping of species richness for conservation of biological diversity: conceptual and methodological issues. Ecological Applications 6, 763-773.

Cox, J., Kautz, R., MacLaughlin, M., Gilbert, T., 1994. Closing the Gaps in Florida's Wildlife Habitat Conservation System. Office of Environmental Services, Florida Game and Fresh Water Fish Commission, Tallahassee.

Davenport, L.B., 1964. Structure of two Peromyscus polionotus populations in old-field ecosystems at the AEC Savannah River plant. Journal of Mammology 45, 95-113.

Extine, D.D., Stout, I.J., 1987. Dispersion and habitat occupancy of the beach mouse, Peromyscus polionotus niveiventris. Journal of Mammology 68, 297-304.

Faust, B.F., Smith, M.H., Wray, W.B., 1971. Distances moved by small mammals as an apparent function of grid size. Acta Theriologica 16, 161-177.

Forys, E. A., 1995. Metapopulations of marsh rabbits: a population viability analysis for the Lower Keys marsh rabbit. PhD Dissertation, University of Florida, Gainesville.

Forys, E.A., Dueser, R.D., 1993. Inter-island movements of rice rats (Oryzomys palustris). American Midland Naturalist 130, 408412.

Franklin, I.A., 1980. Evolutionary change in small populations. In: Soulé, M.E., Wilcox, B.A. (Eds.), Conservation Biology: an evolutionary-ecological perpective. Sinauer Associates, Sunderland, MA, pp. 135-149.

Gilpin, M., Hanski, I., 1991. Metapopulation dynamics: empirical and theoretical investigations. Biological Journal of the Linnean Society $42,1-336$.

Hamilton, W.J., 1941. Notes on some mammals of Lee county, Florida. American Midland Naturalist 25, 686-691.

Harvey, M.J., 1976. Home range movements, and diel activity of the Eastern mole Scalopus aquaticus. American Midland Naturalist 95, 436-445.

HaySmith, L., 1995. Neotoma floridana floridana: natural history, ecology, and movements in north-central Florida. Bulletin of the Florida Museum of Natural History 38, 211-244.

Hickman, G.C., Brown, L.N., 1973. Pattern and rate of mound production in the southeastern pocket gopher (Geomys pintus). Journal of Mammalogy 54, 971-975.
Holzenbein, S., Marchinton, R.L., 1992. Spatial integration of maturing-male white-tailed deer into the adult population. Journal of Mammalogy 73, 326-334.

Howell, J.C., 1954. Populations and home ranges of small mammals on an overgrown field. Journal of Mammalogy 35, 177-186.

Humphrey, S.R. (Ed.), 1992a. Rare and Endangered Biota of Florida: Mammals. University of Florida Press, Gainesville.

Humphrey, S.R., 1992b. Big cypress fox squirrel. In: Humphrey, S.R. (Ed.), Rare and Endangered Biota of Florida: Mammals. University of Florida Press, Gainesville, pp. 224-233.

Hurro, R.L., Reel, S., Landres, P.B., 1987. A critical evaluation of the species approach to biological conservation. Endangered Species Update 4 (12), 1-4.

Ivey, D.R., 1959. The mammals of Palm Valley, Florida. Journal of Mammalogy 40, 585-591.

Jackson, H.T., 1961. Mammals of Wisconsin. University of Wisconsin Press, Madison, WI.

Jones, C., 1990. Microhabitat use by Podomys floridanus in the High Pinelands of Putnam County, Florida. PhD Dissertation, University of Florida.

Jones, C., 1995. Habitat use and home ranges of Podomys floridanus on the Ordway Preserve. Bulletin of the Florida Museum of Natural History 38, 195-210.

Kilgo, J. C., 1992. Effects of environmental influences on home range and activity of adult female white-tailed deer in northern Florida pinelands. MS Thesis University of Florida, Gainesville.

Kinlaw, A.E., Ehrhart, L.M., Doerr, P.D., Pollock, K.P., Hines, J.E., 1995. Population estimate of spotted skunks Spilogale putorius on a Florida Barrier Island. Florida Scientist 58, 48-54.

Landres, P.B., 1983. Use of the guild concept in environmental impact assessment. Environmental Management 7, 393-398.

Landres, P.B., Verner, J., Thomas, J.W., 1988. Ecological uses of vertebrate indicator species: a critique. Conservation Biology 2, 316-328.

Layne, J.N., 1974. Ecology of small mammals in a flatwoods habitat in northcentral Florida, with emphasis on cotton rat (Sigmodon hispidus). American Museum Novitates 2544, 1-48.

Layne, J., 1984. The land mammals of South Florida. In: Gleason, P.J. (Ed.), Environments of South Florida, Past and Present II. Geological Society, Coral Gables, FL, pp. 269-295.

Levins, R.A., 1969. Some demographic and genetic consequences of environmental heterogeneity for biological control. Bulletin of the Entomological Society of America 15, 237-240.

Litvaitis, J.A., Villafuerte, R., 1996. Factors affecting the persistence of New England cottontail metapopulations: the role of habitat management. Wildlife Society Bulletin 24, 686-693.

Maehr, D.S., Land, E.D., Roof, J.C., 1991. Florida panthers. National Geographic Research and Exploration 7, 414-431.

Maehr, D.S., Roof, J.C., Land, E.D., McCowan, J.W., McBride, R.T., 1992. Home range characteristics of a panther in south central Florida. Florida Field Naturalist 20, 97-103.

Miller, R.I. (Ed.), 1994. Mapping the Diversity of Nature. Chapman \& Hall, London.

Moore, J.C., 1946. Mammals from Welaka, Putnam County, Florida. Journal of Mammalogy 27, 49-59.

Noss, R.F., 1990. Indicators for monitoring biodiversity: a hierarchical approach. Conservation Biology 4, 355-364.

Nowak, R.M., 1991. Walker's Mammals of the World, Volume I, 5th Edition. Johns Hopkins University Press, Baltimore, MD.

Odum, E.P., 1955. An eleven year history of a sigmodon population. Journal of Mammalogy 36, 368-378.

Pearson, P.G., 1954. Mammals of Gulf Hammock, Levy County, Florida. American Midland Naturalist 51, 468-480.

Pournelle, G.H., 1950. Mammals of a north Florida swamp. Journal of Mammalogy 31, 310-319.

Prendergast, J.R., Quinn, R.M., Lawton, J.H., 1999. The gaps between theory and practice in selecting nature reserves. Conservation Biology 13, 484-492. 
Pulliam, H.R., 1988. Sources, sinks and population regulation. American Naturalist 132, 652-661.

Reid, D.G., Code, T.E., Reid, A.C.H., Herrero, S.M., 1994. Spacing, movements, and habitat selection of the river otter in boreal Alberta. Canadian Journal of Zoology 72, 1314-1324.

Ryser, J.T., 1995. Activity, movement, and home range of Virginia opossums Didelphis virginiana in Florida. Bulletin of the Florida Museum of Natural History 38, 177-194.

Shafer, C.L., 1990. Nature reserves: island theory and conservation practice. Smithsonian Institution Press, Washington, DC.

Shaffer, M.L., 1981. Minimum population sizes for species conservation. BioScience 31, 131-134.

Scott, J.M., Csuti, B., Jacobi, J.D., Estes, J.E., 1987. Species richness. Bioscience 37, 782-788.

Scott, J.M., Davis, F., Csuti, B., Noss, R., Butterfield, B., Groves, C., Anderson, H., Caicco, S., Derchia, F., Edwards, T.C., Ulliman, J.Jr., Wright, R.G., 1993. Gap analysis: a geographical approach to protection of biological diversity. Wildlife Monograph 123, .

Severinghaus, W.D., 1981. Guild theory development as a mechanism for assessing environmental impact. Environmental Management 5, 187-190.

Sherman, H.B., 1952. The list and bibliography of the mammals of Florida, living and extinct. Quarterly Journal of the Florida Academy of Sciences 15, 100-126.

Shirer, H.W., Fitch, H., 1970. Comparison from radiotracking of movements and denning habits of the raccoon, striped skunk, and opossum in Northeastern Kansas. Journal of Mammalogy 51, 491-503.

Soulé, M.E., 1980. Thresholds for survival: maintaining fitness and evolutionary potential. In: Soulé, M.E., Wilcox, B.A. (Eds.), Conservation Biology: An Evolutionary-Ecological Perpective. Sinauer Associates, Sunderland, MA, pp. 151-169.
Starner, B.A., 1956. Notes on the mammals in three habitats in North Florida. Quarterly Journal of The Florida Academy Of Sciences 19, $153-156$.

Storm, G.L., 1965. Movements and activities of foxes as determined by radio-tracking. Journal of Wildlife Management 29, 1.

Sunquist, M.E., 1989. Comparison of spatial and temporal activity of red foxes and gray foxes in north central Florida. Florida Field Naturalist 17, 11-18.

The Nature Conservancy, 1997. International classification of ecological communities: terrestrial vegetation of the southeastern United States. The Nature Conservancy, Chapel Hill, NC.

Verner, J., 1984. The guild concept applied to management of bird populations. Environmental Management 8, 1-14.

Walker, R. S., 1993. Habitat use, movement, and density of the raccoon (Procyon lotor) in a wetland/sandhill mosaic of north-central Florida. MS Thesis, University of Florida, Gainesville.

Wassmer, D.A., Guenther, D.D., Layne, J.N., 1988. Ecology of the bobcat in South-Central Florida. Bulletin of the Florida State Musuem Biological Sciences 33, 159-228.

Wooding, J.B., 1994. Population dynamics, movement ecology and management of the fox squirrel in Florida. Florida Game and Fresh Water Fish Commission Fianl Report, Tallahassee, FL.

Wooding, J. B., and T. S. Hardisky, 1993. Home range, habitat use, and mortality of black bears in Northcentral Florida. International Conference Bear Research and Management.

Wooding, J.B., Shea, S.M., Richardson, M.L., 1992. Movements of a female black bear in Northwestern Florida. Florida Field Naturalist $20,46-48$. 